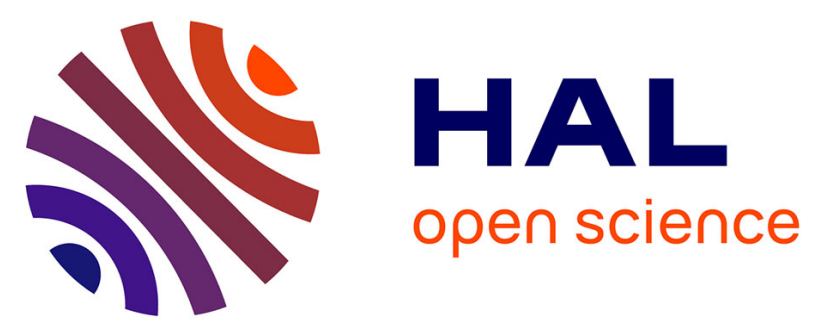

\title{
Strontium isotope tracing of terrigenous sediment dispersal in the Antarctic Circumpolar Current: Implications for constraining frontal positions
}

S. R. Hemming, T. van de Flierdt, S. L. Goldstein, A. M. Franzese, M. Roy, Guillaume Gastineau, G. Landrot

\section{To cite this version:}

S. R. Hemming, T. van de Flierdt, S. L. Goldstein, A. M. Franzese, M. Roy, et al.. Strontium isotope tracing of terrigenous sediment dispersal in the Antarctic Circumpolar Current: Implications for constraining frontal positions. Geochemistry, Geophysics, Geosystems, 2007, 8 (6), 10.1029/2006GC001441 . hal-01332216

\section{HAL Id: hal-01332216 https://hal.sorbonne-universite.fr/hal-01332216}

Submitted on 15 Jun 2016

HAL is a multi-disciplinary open access archive for the deposit and dissemination of scientific research documents, whether they are published or not. The documents may come from teaching and research institutions in France or abroad, or from public or private research centers.
L'archive ouverte pluridisciplinaire HAL, est destinée au dépôt et à la diffusion de documents scientifiques de niveau recherche, publiés ou non, émanant des établissements d'enseignement et de recherche français ou étrangers, des laboratoires publics ou privés. 


\title{
Strontium isotope tracing of terrigenous sediment dispersal in the Antarctic Circumpolar Current: Implications for constraining frontal positions
}

\author{
S. R. Hemming, T. van de Flierdt, and S. L. Goldstein \\ Lamont-Doherty Earth Observatory of Columbia University, 61 Route 9W, Palisades, New York 10964, USA \\ (sidney@ldeo.columbia.edu) \\ Department of Earth and Environmental Sciences, Columbia University, Nerw York, New York 10027, USA
}

A. M. Franzese

Department of Earth and Environmental Sciences, Columbia University, New York, New York 10027, USA

M. Roy

Lamont-Doherty Earth Observatory of Columbia University, 61 Route 9W, Palisades, New York 10964, USA

Now at Département des Sciences de la Terre et de l'Atmosphère, Université du Québec à Montréal, C.P. 8888, Succ. Centre-Ville, Montreal, Quebec, Canada H3C $3 P 8$

\section{G. Gastineau}

Lamont-Doherty Earth Observatory of Columbia University, 61 Route 9W, Palisades, New York 10964, USA

Now at Laboratoire de Meteorologie Dynamique, Université de Paris 6, 4 Place Jussieu, F-75252 Paris Cedex 05, France

\section{G. Landrot}

Lamont-Doherty Earth Observatory of Columbia University, 61 Route 9W, Palisades, New York 10964, USA

Now at Department of Plant and Soil Sciences, University of Delaware, 152 Townsend Hall, Newark, Delaware 19716, USA

[1] The vigor of the glacial Antarctic Circumpolar Current (ACC) and the locations of frontal boundaries are important parameters for understanding the role of the Southern Ocean in global climate change. Toward the goal of understanding the locations of currents we present a survey of Sr isotope ratios in terrigenous sediments around the perimeter of Antarctica. The pattern of the variations within the modern ACC is used to suggest that terrigenous sediment from Antarctica is injected into the ACC via the Ross and Weddell gyres in the south. North of the main ACC the Sr isotopes reflect continental contributions from Africa, Australia-New Zealand, and South America. Along a transect northward from the Ross Sea, Sr isotope ratios show a decrease from higher values in the south (Antarctic provenance) to lower values in the north (provenance from New Zealand). This otherwise monotonic decrease is interrupted within the ACC by a "zigzag" to lower and then higher values, which accompanies minimum terrigenous flux. This zigzag requires contributions from two additional sediment sources beyond the main Antarctic and New Zealand end-members. The lower Sr isotope ratios are attributable to greater contributions from basaltic sources within the current, a consistent pattern around the ACC. The samples with higher Sr isotope ratios point to an additional contributor, possibly a wind-transported component from Australia. During the LGM 
there is a systematic geographical variation in the $\mathrm{Sr}$ isotope ratios, similar to that of the Holocene. A small offset of the zigzag to the north (approximately $1^{\circ}-2^{\circ}$ ) may indicate a small northward shift of the southern boundary of the ACC. More highly resolved data are required to test whether this northward shift is really significant and whether it applies to other ACC fronts during the LGM.

Components: 7748 words, 4 figures, 1 table.

Keywords: strontium isotopes; Antarctica; Antarctic Circumpolar Current; terrigenous sediments; provenance; neodymium isotopes.

Index Terms: 4924 Paleoceanography: Geochemical tracers; 4926 Paleoceanography: Glacial; 4904 Paleoceanography: Atmospheric transport and circulation.

Received 3 August 2006; Revised 21 November 2006; Accepted 12 February 2007; Published 13 June 2007.

Hemming, S. R., T. van de Flierdt, S. L. Goldstein, A. M. Franzese, M. Roy, G. Gastineau, and G. Landrot (2007), Strontium isotope tracing of terrigenous sediment dispersal in the Antarctic Circumpolar Current: Implications for constraining frontal positions, Geochem. Geophys. Geosyst., 8, Q06N13, doi:10.1029/2006GC001441.

Theme: Past Ocean Circulation

Guest Editors: C. Kissel, L. Labeyrie, J. Lynch-Stieglitz, and O. Marchal

\section{Introduction}

[2] The Antarctic Circumpolar Current (ACC) is associated with the strongest winds on Earth and carries the greatest volume of water transport in the world's ocean [e.g., Orsi et al., 1995; Barker and Thomas, 2004], and temporal changes in this system could have global impacts on ocean circulation and climate. Geochemical and modeling studies have suggested that glacial stratification and/or variations in sea ice cover of the Circum-Antarctic could be important for glacial-interglacial variations in atmospheric $\mathrm{pCO}_{2}$ [e.g., Sarmiento and Toggweiler, 1984; Siegenthaler and Wenk, 1984; Francois et al., 1997; Boyle, 1988; Toggweiler, 1999; Stephens and Keeling, 2000; Sigman and Boyle, 2000; Frank et al., 2000; Keeling and Stephens, 2001; Keeling, 2002; Archer et al., 2003; Sigman et al., 2004; Toggweiler et al., 2006]. In spite of the likely importance of the Southern Ocean's role in climate change, there is no consensus about either the location of winds and fronts, or vigor of the ACC in the past.

[3] Toggweiler et al. [2006] suggest that northward displacement of the westerlies during glacial times could have resulted in reduced ventilation of deep waters around the perimeter of Antarctica, and thus provide a potentially important feedback loop for glacial-interglacial $\mathrm{pCO}_{2}$ changes. They reviewed the indications and views about changes in the mean latitude of the westerlies, including observations of shifts over the past 40 years in concert with increasing atmospheric $\mathrm{CO}_{2}$ [Hurrell and van Loon, 1994;
Kushner et al., 2001; Intergovernmental Panel on Climate Change, 2001]. The evidence for recent shifts raises the possibility that the westerlies may shift in different climate conditions. Lines of evidence associated with sea ice extent and biological productivity have led some investigators to conclude that the major Circum-Antarctic fronts shifted northward by as much as $5^{\circ}-10^{\circ}$ in latitude during glacial periods [e.g., Hays et al., 1976; Prell et al., 1980; Mortlock et al., 1991; Howard and Prell, 1992; Gersonde et al., 2005].

[4] On the other hand, some geochemical studies have concluded that the frontal boundaries were similar to today [e.g., Matsumoto et al., 2001; Anderson et al., 2002]. Moreover, physical oceanographers have maintained that the ACC position is "grounded" by the bathymetry [e.g., Moore et al., 1999, 2000; Trathan et al., 2000; Pollard and Read, 2001; Ansorge and Lutjeharms, 2003]. If the ACC flow cannot be moved due to bathymetric control, then the latitudinal changes in biologically sensitive proxies do not reflect frontal shifts but rather reflect changes in productivity due to changing sea ice cover, SST, and nutrient availability independent of the frontal boundaries.

[5] Pollen studies from South America have been interpreted to indicate both northward [Heusser, 1989; Moreno et al., 1999] and southward [Markgraf, 1989] changes in the westerlies track. Lamy and coworkers [Lamy et al., 1999, 2001, 2002; Stuut et al., 2002; Stuut and Lamy, 2004] have used studies of terrigenous sediments from 
marine sediment cores off western South America and Africa to conclude that the westerlies shift northward during cold climate periods.

[6] Barker and Thomas [2004] note that combined effects of lower temperatures, grounding of the ice sheet to the continental shelf edge, and more extensive sea ice coverage during glacial maxima might be expected to cause the belt of driving winds to move northward and reduce ocean-atmosphere coupling, with the overall effect to reduce the strength of the ACC. For example, Ninnemann and Charles [2002] concluded that a less vigorous glacial ACC is indicated by gradients of benthic foraminiferal $\delta^{13} \mathrm{C}$ between the Atlantic and Pacific sectors, and this may be consistent with observations of extremely salty water in the South Atlantic sector of the Southern Ocean [Adkins et al., 2002] during the last glacial maximum (LGM), the carbonate concentration and $\delta^{13} \mathrm{C}$ of benthic carbon [Hodell et al., 2003] and the extremely low radiocarbon content of southwest Pacific waters [Sikes et al., 2000]. On the other hand, a more vigorous glacial ACC might be expected because the presentday ACC core is displaced southward from its driving winds, and glacial wind strengths were greater than today. On the observation side, studies based on grain size variability in the Scotia Sea [Pudsey and Howe, 1998, 2002] conclude that ACC flow intensified during the LGM. Barker and Thomas [2004] note that in addition to grain size variability it is important to consider the possibility of significant glacial-interglacial change in terrigenous sediment sources. In short, the current state of observations and theory fall far short of constraining the situation in the glacial ACC.

[7] Radiogenic isotope tracing of sediment provenance offers a promising solution to this important question. The geometry of the Circum-Antarctic system combined with the isotopically distinctive terrigenous end-members sets up a situation where the pattern of compositional variation can place important limits on the position of the currents. The radiogenic isotope ratios of the terrigenous detritus reflect only source and dispersal, and are independent of parameters that control biological productivity such as temperature and nutrient availability. Meridional changes in the major frontal boundaries will thus be reflected by systematic latitudinal changes in the isotopic compositions of detritus.

\subsection{Terrigenous Sediment Provenance in the $\mathrm{ACC}$}

[8] Terrigenous clastic sediments are brought to the ocean from continental sources via rivers, ice and wind, and distributed within the ocean by surface and deep currents. By investigating longlived radioactive decay systems, the sediment sources can be traced and the geological history of those sources can be delineated (for a recent review, see Goldstein and Hemming [2003]). The perimeter of Antarctica has a large range of basement ages, from Archean terrains to recent volcanism, guaranteeing large contrasts in the isotope ratios of terrigenous sources, which vary systematically around the continent. There is significant outcropping of Archean-Proterozoic basement in East Antarctica, and Phanerozoic rocks, including active volcanoes, in West Antarctica and the Antarctic Peninsula. In a survey of core top sediments around Antarctica, M. Roy et al. $\left({ }^{40} \mathrm{Ar} /{ }^{39} \mathrm{Ar}\right.$ ages of hornblende grains and bulk $\mathrm{Sm} / \mathrm{Nd}$ isotopes of circum-Antarctic glacio-marine sediments: Implications for sediment provenance in the Southern Ocean, submitted to Chemical Geology, 2007; hereinafter referred to as Roy et al., submitted manuscript, 2007) found the following estimates for the average "mantle extraction" or "crustal residence" ages (as reflected by $\mathrm{Nd}$ depleted mantle model ages) and the latest metamorphic overprint (K-Ar ages) from the same Antarctic proximal sediments studied here (Figure 1): (1) Between $155^{\circ} \mathrm{E}$ and $90^{\circ} \mathrm{E}$ (Wilkes Land sector), $\mathrm{Nd}$ model ages average $\sim 2.0 \mathrm{Ga}$. This sector shows the widest range of ${ }^{40} \mathrm{Ar} /{ }^{39} \mathrm{Ar}$ ages, with large peaks in the age spectrum at $1500-1800 \mathrm{Ma}$ and 1100-1300 Ma, smaller peaks at $\sim 400-600 \mathrm{Ma}$ and 0-200 Ma. (2) Moving westward, the Prydz Bay $\left(90^{\circ} \mathrm{E}-55^{\circ} \mathrm{E}\right)$, Dronning Maud Land $\left(55^{\circ} \mathrm{E}-\right.$ $\left.15^{\circ} \mathrm{W}\right)$, and Weddell Sea $\left(15^{\circ} \mathrm{W}-55^{\circ} \mathrm{W}\right)$ sectors have $\mathrm{Nd}$ model ages that become progressively younger, averaging $\sim 2.3 \mathrm{Ga}, \sim 1.9 \mathrm{Ga}$, and $\sim 1.5 \mathrm{Ga}$, respectively. In contrast the ${ }^{40} \mathrm{Ar}{ }^{39} \mathrm{Ar}$ age spectrum is dominated by $400-600 \mathrm{Ma}$ ages, with a small cluster of ages 1100-1300 Ma. (3) Sediments from West Antarctica show the youngest Nd model ages, with the Antarctic Peninsula $\left(55^{\circ} \mathrm{W}-85^{\circ} \mathrm{W}\right)$ and West Antarctica $\left(85^{\circ} \mathrm{W}-140^{\circ} \mathrm{W}\right)$ sectors yielding on average $\sim 1.1 \mathrm{Ga}$. In the ${ }^{40} \mathrm{Ar} /{ }^{39} \mathrm{Ar}$ age spectra, 0-200 Ma ages predominate. (4) The Ross Sea sector $\left(140^{\circ} \mathrm{W}-155^{\circ} \mathrm{E}\right)$ includes contributions from West and East Antarctica, and the average crustal residence age is $\sim 1.3 \mathrm{Ga}$. The ${ }^{40} \mathrm{Ar} /{ }^{39} \mathrm{Ar}$ age spectrum shows large peaks at 0-200 Ma and 400$600 \mathrm{Ma}$, and a few grains at $1200 \mathrm{Ma}, 2600 \mathrm{Ma}$, and 2800 Ma. As discussed by Roy et al. (submitted manuscript, 2007), these sedimentary provenance results are in good agreement with the known geological pattern in Antarctica. 


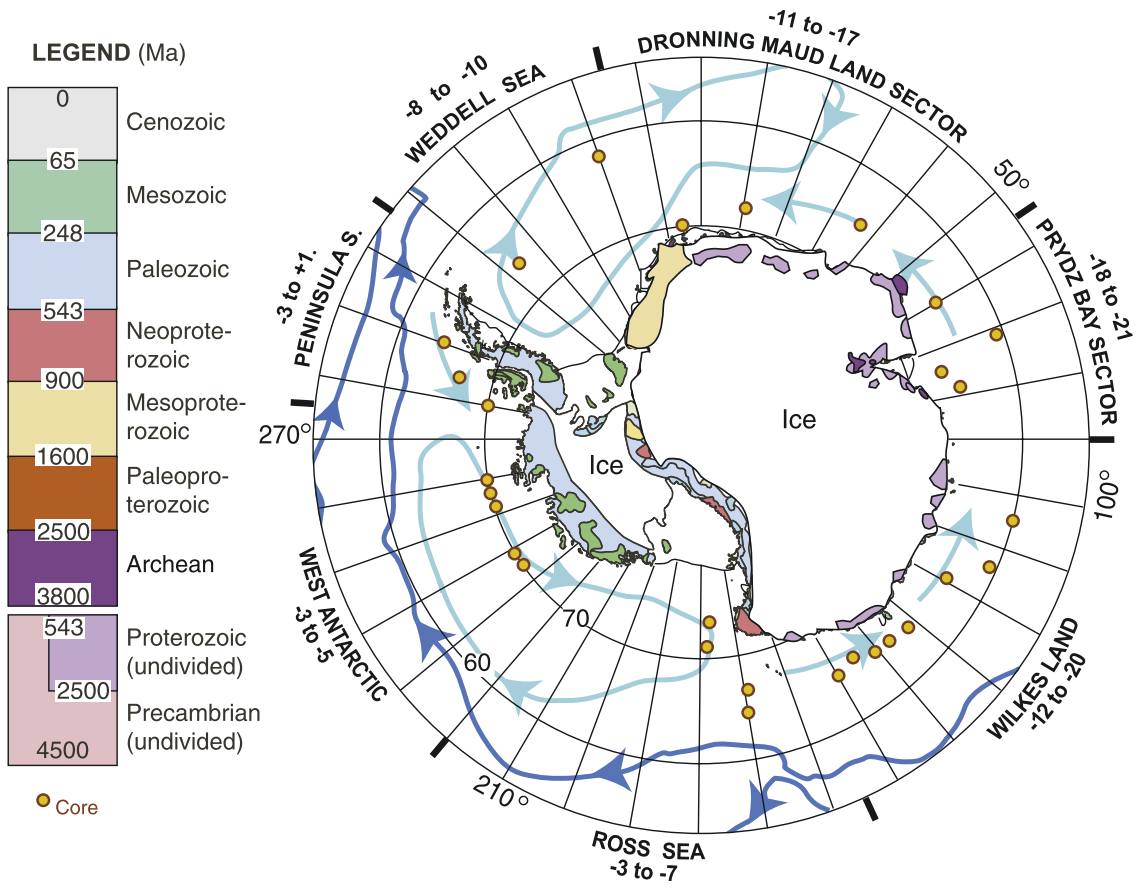

Figure 1. Schematic geological map of Antarctica modified from Kirkham and Chorlton [1995] using the outcrop limits of Dalziel [1992] and locations of marine cores studied. For each location the terrigenous, near-core-top sample has been analyzed. Cores are grouped under seven sectors (labeled on the map; "S." stands for sector where there is not room for the full word) on the basis of ice flow patterns. Each sector is characterized by a range of $\varepsilon_{\mathrm{Nd}}$ values [from Roy et al., submitted manuscript, 2007; van de Flierdt et al., 2007].

\subsection{Goals of This Paper}

[9] In this paper we report the ${ }^{87} \mathrm{Sr} /{ }^{86} \mathrm{Sr}$ of the $<63$ micron terrigenous sediment fractions of Antarctica-proximal core top samples as used by Roy et al. (submitted manuscript, 2007) for $\mathrm{Nd}$ isotopes and ${ }^{40} \mathrm{Ar} /{ }^{39} \mathrm{Ar}$ ages of hornblende grains and by van de Flierdt et al. [2007] to study Nd-Hf isotope systematics of terrigenous sediments. Additionally, we report data from Holocene and glacial samples within the ACC and north of it. Our interpretations also integrate the South Atlantic data sets reported by Walter et al. [2000] and Franzese et al. [2006]. The goal of this paper is to explore the relationships among terrigenous sources of sediment around the perimeter of Antarctica and dispersal within the ACC.

\section{Samples and Methods}

[10] Samples were taken from marine sediment cores from the Lamont and Florida State repositories, dispersed in water and sieved at 63 microns. The $<63$ micron fraction was leached with buffered acetic acid, following the procedure of Biscaye [1965] and with a hydroxylamine hydrochloride solution following the procedure of Rutberg et al. [2000], taken from Chester and Hughes [1967].
Samples with high opal contents were further leached with sodium carbonate solution, following the procedure of Mortlock and Froelich [1989].

[11] Residues from leaching the $<63$ micron fraction were dissolved on a hotplate at $\sim 150^{\circ} \mathrm{C}$ in a mixture of 4:1 $\mathrm{HNO}_{3}$ and $\mathrm{HF}$ for several hours or until no visible solids remained. Dissolved samples were dried, taken up in $3 \mathrm{~N} \mathrm{HNO}_{3}$ and loaded on cleaned and equilibrated $0.03 \mathrm{ml}$ columns of Eichrom's strontium specific resin. Approximately 750 microliters of $3 \mathrm{~N} \mathrm{HNO}_{3}$ was passed through the columns. Strontium was eluted with approximately 750 microliters of quartz-distilled water, and dried for analysis.

[12] Sr was loaded onto tungsten filaments with a $\mathrm{TaCl}_{5}$ solution [Birck, 1986]. Isotope measurements were made on a VG Sector 54 multiple collector thermal ionization mass spectrometer, using a multidynamic collection routine and an exponential fractionation correction based on ${ }^{86} \mathrm{Sr} /{ }^{88} \mathrm{Sr}$ of 0.1194 . Between 100 and 120 ratios were averaged for each analysis. Samples from the Antarctic perimeter were measured in May 2005 and the average of 14 analyses of SRM987 in this interval was $0.710251 \pm 0.000033,2 \sigma$ external reproducibility. Samples from the ACC and to the 
north of the ACC were measured during June through August of 2003 and the average of 51 analyses of SRM987 in this interval was $0.710263 \pm 0.000022,2 \sigma$ external. We have corrected the values to the recommended value of 0.710245 using the measurements near the time of the analyses due to the two-year separation in time. The range of values for sediment samples reported here is in the second decimal place, and therefore uncertainties for the standard data in the fifth decimal place are trivial.

\section{Results and Discussion}

[13] Strontium isotope data are reported in Table 1, and core top and LGM values are shown on the map in Figure 2. Sr and Nd isotopes are compared in Figure 3.

\subsection{Isotope Systematics}

[14] Strontium isotope values around Antarctica range from 0.705 to 0.739 . Together, Nd-Sr isotopes on these samples show a good correspondence with global sediment compositions (Figure 3), although in detail they tend toward higher ${ }^{87} \mathrm{Sr} /{ }^{86} \mathrm{Sr}$ relative to the global sediment array. Because the Sm-Nd system provides an estimate of the average "mantle extraction" age [e.g., McCulloch and Wasserburg, 1978; DePaolo, 1981; Goldstein et al., 1984, 1997; Taylor and McLennan, 1985; McLennan and Hemming, 1992; Roy et al., submitted manuscript, 2007], the strong covariation between $\varepsilon_{\mathrm{Nd}}$ and ${ }^{87} \mathrm{Sr} /{ }^{86} \mathrm{Sr}$ confirms the first order importance of geologic age on the strontium isotopes [e.g., Dasch et al., 1966; Dasch, 1969; Biscaye and Dasch, 1971; Goldstein and Jacobsen, 1988]. Additional factors that influence the Rb-Sr system more than the Sm-Nd system are weathering and sedimentary sorting (reviewed by Goldstein and Hemming [2003]). It is likely that the tendency to higher ${ }^{87} \mathrm{Sr} /{ }^{86} \mathrm{Sr}$ for a given $\varepsilon_{\mathrm{Nd}}$ in Antarctic samples is due to the dominance of physical over chemical weathering in this glacial environment. This is an interesting observation, but it is of limited relevance to this paper and will be pursued elsewhere.

\subsection{Mechanisms for Transporting Terrigenous Sediment to the Ocean}

[15] As the weathering products of rocks exposed at the surface of the earth, terrigenous sediments provide important insights into paleo-conditions. The rock types sampled by weathering, as well as the type and degree of dominant weathering and the geological history of the terrains they sample, particularly the ages of significant events such as crust formation and metamorphism, lead to distinctive variability in their radiogenic isotope compositions. Terrigenous sediments are delivered to the ocean by glaciers and rivers with generally high flux near point sources, decreasing rapidly away from them and contributing to hemipelagic sediments that are moved around the ocean by currents (both surface and deep currents, depending on the situation; see discussion by Franzese et al. [2006]). Terrigenous sediments are also delivered to the ocean by winds, but in general the vastly greater hemipelagic rain rate means that wind delivered sediment is rarely a large fraction of the terrigenous sediment supply. This means that, apart from areas where the terrigenous flux is very low $(\ll 100 \mathrm{mg} /$ $\mathrm{cm}^{2} / \mathrm{kyr}$ ), it is unlikely that wind blown sources can be identified from sediment compositions. Examples where wind delivered sediments are predominant include regions far removed from continents, such as the central North Pacific Ocean. Additionally, regions very close to major dust sources, such as the eastern Atlantic off the Sahara desert, also have a dominant wind delivered sediment composition. For a general overview of terrigenous sediments in marine deposits, the reader is referred to recent reviews by Kohfeld and Harrison [2001] and Grousset and Biscaye [2005].

\subsection{Geographic Trends Revealed by Core Top Survey}

[16] Different basement provinces yield distinctive isotopic signatures, where in general older sources yield higher ${ }^{87} \mathrm{Sr} /{ }^{86} \mathrm{Sr}$ (Figures 1 and 2). Within the $\mathrm{ACC}$, the terrigenous detritus shows distinctive meridional zonations in transects from the Antarctic continent (Figure 2). Both south and north from the main $\mathrm{ACC}$, the ${ }^{87} \mathrm{Sr} /{ }^{86} \mathrm{Sr}$ of the terrigenous detritus reflects continental components from Antarctica in the south, and Africa, Australia-New Zealand, and South America in the north. The detritus within the main ACC has a large component derived from recent volcanism that is especially strong east of the Antarctic Peninsula and the South Sandwich island arc (east of Drake Passage, DP). This signal is carried far eastward by the ACC and is reinforced by the Crozet Islands (CI) and presumably also by volcanism of the Kerguelen Plateau (KP). Thus the geometry of the system combined with the geological variability facilitates the use of isotopic tracers to follow dispersal by currents. 
Table 1. Strontium Isotope Data From Circum-Antarctic and ACC Samples

\begin{tabular}{|c|c|c|c|c|c|c|}
\hline Core & Latitude & Longitude & Depth, cm & Age & ${ }^{87} \mathrm{Sr} /{ }^{86} \mathrm{Sr}$ & $\begin{array}{l} \pm 0.0000 x x \\
\text { (in Run) }\end{array}$ \\
\hline \multicolumn{7}{|c|}{ South Pacific Holocene } \\
\hline NBP9802_1MC2 & -76.49 & -181.9 & 3 & Holocene & 0.721677 & 10 \\
\hline NBP9802_2MC1 & -73.54 & -183.04 & & Holocene & 0.715299 & 09 \\
\hline NBP9802_3MC2 & -66.14 & -169.49 & 7 & Holocene & 0.713991 & 13 \\
\hline NBP9802_4MC1 & -64.2 & -170.08 & 5 & Holocene & 0.710908 & 14 \\
\hline NBP9802_5MC2 & -63.17 & -169.85 & 2.5 & Holocene & 0.711794 & 23 \\
\hline NBP9802_6MC1 & -61.87 & -169.97 & 7 & Holocene & 0.712176 & 14 \\
\hline NBP9802_7MC1 & -60.24 & -170.19 & 3.5 & Holocene & 0.711144 & 16 \\
\hline NBP9802_8MC1 & -58.69 & -169.98 & 7 & Holocene & 0.709287 & 13 \\
\hline NBP9802_9MC1 & -56.94 & -170.23 & 5.5 & Holocene & 0.709241 & 09 \\
\hline NBP9802_10MC1 & -53.04 & -174.69 & 3.5 & Holocene & 0.708226 & 08 \\
\hline E11-2 & -56.07 & -115.09 & 29.5 & Holocene & 0.710296 & 16 \\
\hline E17-9 & -63.08 & -135.08 & 21 & Holocene & 0.709953 & 09 \\
\hline E20-10 & -60.22 & -127.05 & 51 & Holocene & 0.711246 & 17 \\
\hline E33-22 & -54.93 & -120 & 11.5 & Holocene & 0.709998 & 21 \\
\hline \multicolumn{7}{|c|}{ South Pacific LGM } \\
\hline NBP9802_3GC1 & -66.13 & -169.5 & 11 & LGM & 0.714092 & 07 \\
\hline NBP9802_4GC1 & -64.2 & -170.08 & 30 & LGM & 0.711952 & 09 \\
\hline NBP9802_5GC1 & -63.11 & -169.74 & 47 & LGM & 0.710735 & 09 \\
\hline rep - & & & & & 0.710725 & 10 \\
\hline NBP9802_6PC1 & -61.88 & -169.98 & 185.5 & LGM & 0.715128 & 09 \\
\hline NBP9802_9PC1 & -56.9 & -170.2 & 60.5 & LGM & 0.712128 & 10 \\
\hline E11-2 - & -56.07 & -115.09 & 166.5 & LGM & 0.710651 & 07 \\
\hline E17-9 & -63.08 & -135.08 & 181 & LGM & 0.710855 & 10 \\
\hline E20-10 & -60.22 & -127.05 & 251 & LGM & 0.710608 & 10 \\
\hline E20-10 & -54.93 & -120 & 64.5 & LGM & 0.708966 & 09 \\
\hline \multicolumn{7}{|c|}{ South Atlantic and Indian Holocene } \\
\hline V17-91 & -61.18 & -75.93 & $7-8$ & Holocene & 0.706946 & 04 \\
\hline $\mathrm{RC} 11-46$ & -43.37 & -36.1 & 10 & Holocene & 0.709916 & 04 \\
\hline $\mathrm{RC} 11-76$ & -54.38 & -22.13 & $9-10$ & Holocene & 0.713399 & 11 \\
\hline $\mathrm{RC} 11-77$ & -53.05 & -16.45 & $38-40$ & Holocene & 0.710432 & 04 \\
\hline $\mathrm{RC} 11-78$ & -50.87 & -9.87 & $9-10$ & Holocene & 0.709935 & 04 \\
\hline RC11-80 & -46.75 & -0.05 & 10 & Holocene & 0.710681 & 07 \\
\hline $\mathrm{RC} 13-255$ & -50.58 & 2.9 & 10 & Holocene & 0.712999 & 07 \\
\hline $\mathrm{RC} 13-254$ & -48.57 & 5.13 & $9-10$ & Holocene & 0.711339 & 11 \\
\hline $\mathrm{RC} 13-251$ & -42.52 & 11.67 & $2-3$ & Holocene & 0.714206 & 04 \\
\hline V29-84 & -43.85 & 27.6 & $3.4-5.6$ & Holocene & 0.709249 & 04 \\
\hline V29-86 & -49.57 & 30.02 & $7-8$ & Holocene & 0.713882 & 06 \\
\hline $\mathrm{RC} 17-60$ & -44.5 & 31.18 & 10 & Holocene & 0.709874 & 04 \\
\hline RC17-53 & -57.48 & 36.17 & $4-5$ & Holocene & 0.707678 & 06 \\
\hline $\mathrm{RC} 17-58$ & -53.52 & 36.63 & 10 & Holocene & 0.710589 & 06 \\
\hline $\mathrm{RC} 17-63$ & -45.65 & 48.28 & $3-4$ & Holocene & 0.703868 & 06 \\
\hline RC14-11 & -38.00 & 51.18 & 5.6 & Holocene & 0.714613 & 04 \\
\hline RC17-61 & -52.2 & 54.47 & 10 & Holocene & 0.708249 & 05 \\
\hline RC11-96 & -50.47 & 59.58 & $3.4-9.10$ & Holocene & 0.709322 & 11 \\
\hline V24-203 & -36.98 & 59.98 & $2.3-3.4$ & Holocene & 0.705947 & 04 \\
\hline RC11-119 & -40.3 & 74.57 & $10-15$ & Holocene & 0.710725 & 05 \\
\hline RC11-80 & -46.75 & -0.05 & 10 & Holocene & 0.710703 & 09 \\
\hline \multicolumn{7}{|c|}{ South Atlantic and Indian LGM } \\
\hline $\mathrm{RC} 11-46$ & -43.37 & -36.1 & 300 & LGM & 0.709081 & 04 \\
\hline $\mathrm{RC} 12-289$ & -47.95 & -23.7 & 60 & LGM & 0.709265 & 06 \\
\hline $\mathrm{RC} 11-76$ & -54.38 & -22.13 & $438-439$ & LGM & 0.710805 & 30 \\
\hline RC11-77 & -53.05 & -16.45 & 200 & LGM & 0.709372 & 04 \\
\hline $\mathrm{RC} 13-256$ & -53.18 & -0.35 & 390 & LGM & 0.708990 & 04 \\
\hline $\mathrm{RC} 11-80$ & -46.75 & -0.05 & 95 & LGM & 0.710119 & 03 \\
\hline $\mathrm{RC} 13-255$ & -50.58 & 2.9 & 320 & LGM & 0.708034 & 04 \\
\hline $\mathrm{RC} 13-254$ & -48.57 & 5.13 & $270-271$ & LGM & 0.712455 & 04 \\
\hline $\mathrm{RC} 13-251$ & -42.52 & 11.67 & $18-19$ & LGM & 0.710954 & 04 \\
\hline
\end{tabular}


Table 1. (continued)

\begin{tabular}{|c|c|c|c|c|c|c|}
\hline Core & Latitude & Longitude & Depth, cm & Age & ${ }^{87} \mathrm{Sr} /{ }^{86} \mathrm{Sr}$ & $\begin{array}{c} \pm 0.0000 x x \\
\text { (in Run) }\end{array}$ \\
\hline V29-84 & -43.85 & 27.6 & 120 & LGM & 0.712521 & 05 \\
\hline V29-86 & -49.57 & 30.02 & $181-182$ & LGM & 0.708507 & 05 \\
\hline $\mathrm{RC} 17-53$ & -57.48 & 36.17 & $39-40$ & LGM & 0.711768 & 04 \\
\hline RC14-11 & -38.00 & 51.18 & $79-80$ & LGM & 0.710242 & 04 \\
\hline RC11-94 & -54.48 & 53.05 & 480 & LGM & 0.710579 & 05 \\
\hline RC11-95 & -52.8 & 54.08 & $99-100$ & LGM & 0.709885 & 05 \\
\hline RC17-61 & -52.2 & 54.47 & 260 & LGM & 0.710931 & 05 \\
\hline RC11-96 & -50.47 & 59.58 & $100-101$ & LGM & 0.709582 & 04 \\
\hline V24-203 & -36.98 & 59.98 & $179-180$ & LGM & 0.706217 & 04 \\
\hline RC11-119 & -40.3 & 74.57 & $43-44$ & LGM & 0.713113 & 09 \\
\hline \multicolumn{7}{|c|}{ Circum-Antarctica Holocene } \\
\hline IO1277-25 & -68.61 & 10.97 & & & 0.715989 & 05 \\
\hline RC17-56 & -65.40 & 36.72 & & & 0.730219 & 09 \\
\hline $\mathrm{RC} 17-51$ & -65.65 & 60.68 & & & 0.741609 & 13 \\
\hline ELT47-14 & -61.12 & 71.27 & & & 0.728087 & 08 \\
\hline ELT47-07 & -66.66 & 77.90 & & & 0.737219 & 09 \\
\hline ELT50-13 & -60.00 & 105.00 & & & 0.730345 & 05 \\
\hline ELT11-17 & -61.04 & 114.81 & & & 0.710616 & 08 \\
\hline ELT50-18 & -64.43 & 119.98 & & & 0.734381 & 08 \\
\hline ELT37-13 & -64.67 & 132.98 & & & 0.727889 & 09 \\
\hline ELT37-10 & -65.22 & 137.88 & & & 0.738862 & 07 \\
\hline ELT37-09 & -65.55 & 141.10 & & & 0.737042 & 05 \\
\hline ELT37-06 & -66.08 & 145.02 & & & 0.724900 & 06 \\
\hline ELT37-04 & -64.83 & 150.49 & & & 0.725643 & 06 \\
\hline ELT27-20 & -71.96 & 178.60 & & & 0.714642 & 06 \\
\hline ELT33-11 & -70.10 & -122.26 & & & 0.709086 & 06 \\
\hline ELT33-12 & -70.00 & -120.17 & & & 0.712846 & 06 \\
\hline ELT50-16 & -70.17 & -106.64 & & & 0.731820 & 07 \\
\hline ELT11-18 & -70.14 & -102.82 & & & 0.709790 & 05 \\
\hline ELT11-19 & -70.42 & -99.26 & & & 0.707928 & 06 \\
\hline ELT05-20 & -67.18 & -74.78 & & & 0.708198 & 07 \\
\hline ELT05-22 & -65.95 & -70.25 & & & 0.705281 & 05 \\
\hline ELT07-11 & -66.50 & -45.62 & & & 0.725357 & 06 \\
\hline IO1578-48 & -62.00 & -20.01 & & & 0.729523 & 06 \\
\hline IO1277-41 & -70.00 & -5.08 & & & 0.721725 & 07 \\
\hline
\end{tabular}

[17] In the Atlantic sector, southern South America, as well as the Antarctic Peninsula and the Scotia Arc, contribute low ${ }^{87} \mathrm{Sr} /{ }^{86} \mathrm{Sr}$ terrigenous sediments. In contrast East Antarctica on the south and South Africa on the north contribute very high ${ }^{87} \mathrm{Sr} /{ }^{86} \mathrm{Sr}$ terrigenous sediments. The pattern of $\mathrm{Sr}$ isotope variation in the Atlantic sector of the Southern Ocean is consistent with a substantial contribution from high ${ }^{87} \mathrm{Sr} /{ }^{86} \mathrm{Sr}$ sediments derived from the old terrains on the east side of the Weddell Sea being diluted by low ${ }^{87} \mathrm{Sr} /{ }^{86} \mathrm{Sr}$ sediments derived from the young terrains that surround the Drake Passage (Figure 2).

[18] The pattern of Sr isotope variation in the Ross Sea Sector (Figure 2) reveals decreasing values to the north and east. The highest values originate from the East Antarctic side of the Ross Sea. Values near the Ross Sea are consistent with average ${ }^{87} \mathrm{Sr} /{ }^{86} \mathrm{Sr}$ of $0.721 \pm 0.004$ (1 standard deviation of 20 samples from the Ross Shelf and eastern, central and western Ross Sea) from glaciogenic sediments in the outer part of the Ross Sea [Farmer et al., 2006].

[19] Chase et al. [2003] and Sayles et al. [2001] used ${ }^{230} \mathrm{Th}_{\mathrm{xs}}$ to document the vertical flux of sediment components in the Ross Sea sector of the ACC (Figure 4, top panel). Lithogenic (=terrigenous) fluxes are higher at the northern and southern transect limits in Holocene samples, and are generally higher with a less pronounced gradient in LGM samples. The flux pattern in the Holocene implies contributions from Antarctica in the south and from New Zealand (Campbell Plateau) in the north. Franzese et al. [2006] demonstrated the power of combining terrigenous flux and provenance observations to quantify mixing contribu- 


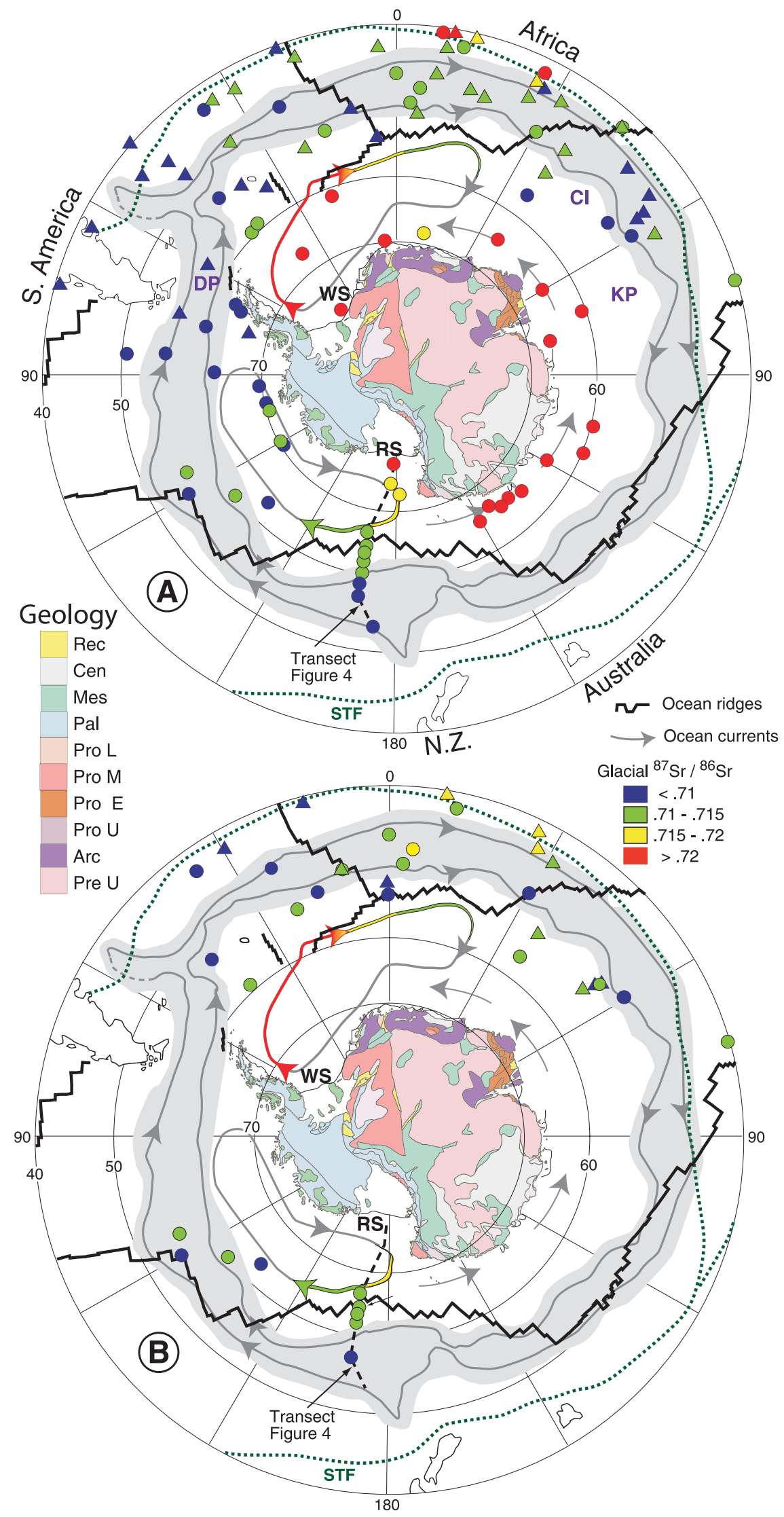

Figure 2 


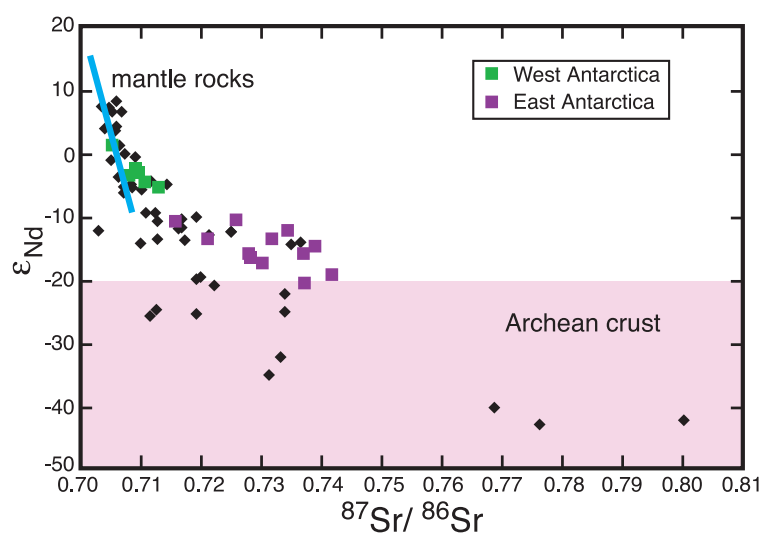

Figure 3. Covariation of $\varepsilon_{\mathrm{Nd}}$ and ${ }^{87} \mathrm{Sr} /{ }^{86} \mathrm{Sr}$ of circumAntarctic terrigenous sediments. Data for modern river suspended sediments [Goldstein and Jacobsen, 1988] and modern deep sea turbidites [McLennan et al., 1990] are shown as black diamonds for reference.

tions to terrigenous sediments in the ocean. The samples taken from the Ross Sea - New Zealand transect (Figure 4, bottom panel) are from the same cores studied by Chase et al. [2003] and thus the provenance data are complemented by flux estimates. The ${ }^{87} \mathrm{Sr} /{ }^{86} \mathrm{Sr}$ along this section is higher near Antarctica and follows a generally decreasing trend away. This trend is entirely consistent with the interpretation made on the basis of the pattern of terrigenous flux [Chase et al., 2003].

[20] Superimposed on this decreasing trend is a minimum in ${ }^{87} \mathrm{Sr} /{ }^{86} \mathrm{Sr}$ at approximately the position of the southern boundary of the ACC, followed by a maximum just to the north of the minimum. This is within the zone of minimum terrigenous flux as documented by Chase et al. [2003] with total terrigenous flux less than $50 \mathrm{mg} / \mathrm{cm}^{2} / \mathrm{kyr}$ (Figure 4). Although these differences in ${ }^{87} \mathrm{Sr} /{ }^{86} \mathrm{Sr}$ may appear small compared to the very large difference in Ross Sea versus other Antarctic end-members, the compositional variations along the Holocene Ross Sea transect are far greater than the external reproducibility of the $\mathrm{Sr}$ isotope ratio. These reversals in trend require additional end-member contributors to the terrigenous sediment load at these sites beyond those identified as the Antarctic continent to the south and New Zealand/Campbell Plateau to the north. The most likely explanation for the local ${ }^{87} \mathrm{Sr} /{ }^{86} \mathrm{Sr}$ minimum is a greater relative contribution from the Pacific-Antarctic ridge to the west with typical MORB values of $\sim 0.703$ [e.g., Klein et al., 1988]. The pattern of minima in ${ }^{87} \mathrm{Sr} /{ }^{86} \mathrm{Sr}$ in the center of the ACC, and especially downstream of major volcanic bathymetric highs, is repeated around the ACC (Figure 2). The local ${ }^{87} \mathrm{Sr} /{ }^{86} \mathrm{Sr}$ maximum just to the north of the minimum is also within the low flux zone of Chase et al. [2003], and may very well signal the presence of a small windblown dust input from much higher ${ }^{87} \mathrm{Sr} /{ }^{86} \mathrm{Sr}$ Australian sources with an average value of about 0.737 [Basile et al., 1999; Delmonte et al., 2004; Revel-Rolland et al., 2006].

\subsection{Holocene-LGM Comparisons}

[21] Compared with the Holocene section from the Ross Sea, sediments from the LGM follow a similar geographic trend in ${ }^{87} \mathrm{Sr} /{ }^{86} \mathrm{Sr}$. However, the position of the minimum ${ }^{87} \mathrm{Sr} /{ }^{86} \mathrm{Sr}$ is located to the north of the Holocene minimum (Figure 4, bottom panel), implying a shift from $\sim 64-65^{\circ} \mathrm{S}$ in the Holocene to $\sim 63^{\circ} \mathrm{S}$ in the LGM (i.e., $1-2^{\circ}$ north). Additionally, the sample to the north of the minimum has a much higher ${ }^{87} \mathrm{Sr} /{ }^{86} \mathrm{Sr}$ in the LGM, consistent with a stronger dust source from Australia in glacial times. Once again, the compositional shifts are significant and require end-members

Figure 2. Strontium isotope composition of terrigenous sediments presented on a polar projection, including a schematic ACC (gray), plus ocean currents near the Antarctic margin and a geologic map of Antarctica modified from Kirkham and Chorlton [1995]. The abbreviations for the geology legend are Rec (Recent), Cen (Cenozoic), Mes (Mesozoic), Pal (Paleozoic), Pro L (Late Proterozoic), Pro M (Middle Proterozoic), Pro E (Early Proterozoic), Pro U (Proterozoic, undivided), Arc (Archean), and Pre U (Precambrian, undivided). The Ross and Weddell Seas are indicated by RS and WS, respectively. Continental sources north of the ACC are indicated by labels (NZ stands for New Zealand). The location of the Ross Sea transect (Figure 4) is indicated. The color variations of the Ross and Weddell Sea gyres are schematic and based on the Holocene data in Figure 2a and our interpretation that these gyres are important point sources for injecting terrigenous sediments into the ACC. Locations from this study are shown as circles, and those from published work (cited in text) are shown as triangles. Color coding of isotopic values is indicated in the legend. (a) The silicate fraction $(<63 \mu \mathrm{m}){ }^{87} \mathrm{Sr} /{ }^{86} \mathrm{Sr}$ of near-core-top sediments, including the survey samples of Figure 1 and cores from the Antarctic Circumpolar Current (ACC). Locations of Drake Passage (DP), Crozet Islands (CI), and Kerguelen Plateau (KP) are indicated in Figure 2 b. (b) $\mathrm{The}{ }^{87} \mathrm{Sr} /{ }^{86} \mathrm{Sr}$ for the fine silicate fraction $(<63 \mu \mathrm{m})$ of LGM sediments from the Antarctic Circumpolar Current (ACC). 


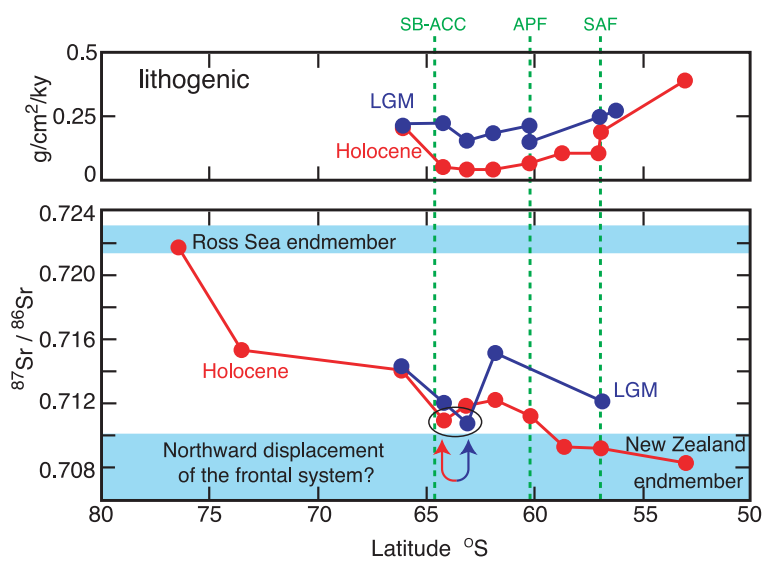

Figure 4. (top) Flux of terrigenous detritus (lithogenic) in the Holocene (blue) and LGM (red) from Chase et al. [2003]. Approximate positions of modern sub-Antarctic Front (SAF), Antarctic Polar Front (APF), and southern boundary of the ACC (SB-ACC) are indicated by vertical lines. (bottom) ${ }^{87} \mathrm{Sr} /{ }^{86} \mathrm{Sr}$ of terrigenous detritus from Holocene (blue) and LGM (red) samples from the same cores. The Ross Sea endmember identified by this survey and highlighted with blue shading has relatively high ${ }^{87} \mathrm{Sr} /{ }^{86} \mathrm{Sr}(\sim 0.721)$ based on the marine sediment data and supported by data from Ross Sea tills [Farmer et al., 2006]. The local, high flux "New Zealand" end-member, also highlighted with blue shading, has lower ${ }^{87} \mathrm{Sr} /{ }^{86} \mathrm{Sr}(\sim 0.708)$ based on the marine sediment data and supported by data from New Zealand igneous rocks (GEOROC database as well as sediment data from Basile et al. [1999], Delmonte et al. [2004], and Revel-Rolland et al. [2006]).

beyond the two obvious sources from New Zealand and Antarctica. Thus changes in terrigenous flux from the Antarctic and New Zealand end-members are not sufficient to explain either the existence or the shift in the zigzag pattern with latitude.

[22] Although more data would be necessary to firmly conclude that a small northward shift in the southern boundary of the ACC occurred between the Holocene and the LGM, the results from the Ross Sea transect nevertheless are consistent with observations in the Cape Basin of the South Atlantic. Holocene and LGM maps of $\mathrm{Sr}$ isotope variations for the South Atlantic have been constructed by Franzese et al. [2006], who found significantly decreased contribution of Agulhas Current derived sediment into the South Atlantic in glacial times. Although the LGM data are sparse within the ACC, cores from near the southern tip of Africa show much less influence from the Agulhas Current compared to the Holocene. Work is ongoing to constrain the position of the Agulhas Retro- flection in the LGM, but it appears likely that it shifted north and/or east in the LGM relative to the Holocene, consistent with a northward shift of the westerlies [Franzese et al., 2006].

\subsection{LGM Shifts and Possible Implications}

[23] Did the major oceanic frontal systems of the Circum-Antarctic shift significantly during the LGM? As reviewed in the introduction, changes in these fronts could be tied to changes in the position of the southern midlatitude westerlies, and this could be an important factor governing Holocene-LGM variations in atmospheric $\mathrm{pCO}_{2}$. In today's ACC, the fronts are the location of the fast currents or jets [Colling, 2001]. From the pattern of provenance variability indicated by the ${ }^{87} \mathrm{Sr} /{ }^{86} \mathrm{Sr}$ of the terrigenous fraction of marine sediment cores, it appears that sediments from various sources are injected into the ACC and then carried in streaks by the currents until they settle through the water column. If this can be demonstrated to be a robust conclusion, then changes in the positions of compositional gradients in terrigenous sediments would be a sensitive tool for mapping the paleo-locations of fast currents. Although we consider the data presented here to demonstrate the potential power of this approach, more data are needed in order to make a firm conclusion about the relationships between changing sediment composition and frontal boundaries. Nevertheless we are intrigued by what appears to us to be a significant relationship. In this context, we will improve the data coverage, spatially, temporally and compositionally with a combination of radiogenic isotopes, flux and other compositional measures including chemistry and grain size.

\section{Conclusions}

[24] The strontium isotope composition of terrigenous detritus is a powerful tracer of continental inputs into the ACC. The sediments deposited along the Antarctic coast represent a mixture of lithologies that were incorporated progressively during glacial transport, and their compositions reflect the variety of bedrock lithologies underlying different sectors of the ice sheet. The different basement provinces yield distinctive isotopic signatures, and the sediments contain information about Antarctic basement ages and Antarctica's geological evolution. The geographic pattern of variability of ${ }^{87} \mathrm{Sr} /{ }^{86} \mathrm{Sr}$ found in this study is created by continental inputs north and south of the ACC and by contributions from oceanic vol- 
canic sources within the ACC. The core top distribution, especially considering the Ross Sea - New Zealand transect, is consistent with our interpretation that provenance change across the ACC is partly controlled by the position of fast currents in the ACC, and thus may be used to estimate changes in them in the past.

[25] A comparison of Holocene and LGM compositions from the Pacific and Atlantic sectors reveals a small northward shift in the zone of minimum ${ }^{87} \mathrm{Sr} /{ }^{86} \mathrm{Sr}$, which may be interpreted as a small northward shift of the southern boundary of the ACC. Further work will be necessary to confirm this conclusion, but the data strongly suggest that the radiogenic isotope ratios in terrigenous sediments are important tools for constraining paleoocean circulation. Because they are controlled by fundamentally different factors than biologically based proxies, they present a complementary and independent view of the system.

\section{Acknowledgments}

[26] The authors gratefully acknowledge support for this work from NSF OPP00-88054 to Steven L. Goldstein and Sidney R. Hemming. The paper was improved due to critical reviews of Jean Lynch-Stieglitz, Ellen Martin, and an anonymous reviewer. The data for this paper have come together from multiple efforts, including internship projects by French undergraduates Guillaume Gastineau (Ross Sea transect) and Gautier Landrot (Atlantic sector) in the spring and summer of 2003. The graduate student support for Allison Franzese has come from the Graduate School of Arts and Sciences at Columbia University, NOAA, and an NSF Graduate Fellowship. Postdoctoral support for Tina van de Flierdt came from a Lamont Postdoctoral Fellowship and Gary Comer Science and Education Foundation Fellowship, and support for Martin Roy came from NSF-OPP and NOAA. We appreciate samples and discussions with Bob Anderson and Marty Fleisher, and help with selecting cores from Lloyd Burckle. Thanks go to Gary Hemming for his help maintaining the mass spectrometer facility. Samples used in this study are from the Antarctic Core Repository at Florida State and from LDEO. This is LDEO contribution 7030.

\section{References}

Archer, D. E., P. A. Martin, J. Milovich, V. Brovkin, G. Plattner, and C. Ashendel (2003), Model sensitivity in the effect of Antarctic sea ice and stratification on atmospheric $p \mathrm{CO}_{2}$, Paleoceanography, 18(1), 1012, doi:10.1029/ 2002PA000760.

Adkins, J. F., K. McIntyre, and D. P. Schrag (2002), The salinity, temperature, and $\delta^{18} \mathrm{O}$ of the glacial deep ocean, Science, 298, 1769-1773.

Anderson, R. F., Z. Chase, M. Q. Fleisher, and J. Sachs (2002), The Southern Ocean's biological pump during the Last Glacial Maximum, Deep Sea Res., Part II, 49, 1909-1938.

Ansorge, I. J., and J. R. E. Lutjeharms (2003), Eddies originating at the south west Indian Ridge, J. Mar. Syst., 39, $1-18$.

Barker, P. F., and E. Thomas (2004), Origin, signature and palaeoclimatic influence of the Antarctic Circumpolar Current, Earth Sci. Rev., 66, 143-162.

Basile, I., F. E. Grousset, M. Revel, J. R. Petit, P. E. Biscaye, and N. I. Barkov (1999), Patagonian origin of glacial dust deposited in East Antarctica (Vostok and Dome C) during glacial stages 2, 4 and 6, Earth Planet. Sci. Lett., 146, 573589.

Birck, J. L. (1986), Precision K-Rb-Sr isotopic analysis: Application to Rb-Sr chronology, Chem. Geol., 56, 73-83.

Biscaye, P. E. (1965), Mineralogy and sedimentation of recent deep-clay in the Atlantic Ocean and adjacent seas and oceans, Geol. Soc. Am. Bull., 76, 803-832.

Biscaye, P. E., and E. J. Dasch (1971), The rubidium, strontium, strontium-isotope system in deep-sea sediments: Argentine Basin, J. Geophys. Res., 76, 5087-5096.

Boyle, E. A. (1988), Vertical oceanic nutrient fractionation and glacial/interglacial $\mathrm{CO}_{2}$ cycles, Nature, 331, 55-56.

Chase, Z., R. F. Anderson, M. Q. Fleisher, and P. W. Kubik (2003), Accumulation of biogenic and lithogenic material in the Pacific sector of the Southern Ocean during the past 40,000 years, Deep Sea Res., Part II, 50, 799-832.

Chester, R., and M. J. Hughes (1967), A chemical technique for the separation of ferro-manganese minerals, carbonate minerals and adsorbed trace elements from pelagic sediments, Chem. Geol., 2, 249-262.

Colling, A. (2001), Ocean Circulation, 2nd ed., 286 pp., Elsevier, New York.

Dalziel, I. W. D. (1992), Antarctica: A tale of two supercontinents?, Annu. Rev. Earth Planet. Sci., 20, 501-526.

Dasch, E. J. (1969), Strontium isotopes in weathering profiles, deep-sea sediments, and sedimentary rocks, Geochim. Cosmochim. Acta, 33, 1521-1552.

Dasch, E. J., F. A. Hills, and K. K. Turckian (1966), Strontium isotopes in deep-sea sediments, Science, 153, 295-297.

Delmonte, B., I. Basile-Doelsch, J.-R. Petit, V. Maggi, M. Revel-Rolland, A. Michard, E. Jagoutz, and F. Grousset (2004), Comparing the Epica and Vostok dust records during the last 220,000 years: Stratigraphical correlation and provenance in glacial periods, Earth Sci. Rev., 66, 63-87.

DePaolo, D. J. (1981), A neodymium and strontium isotopic study of the Mesozoic calc-alkaline granitic batholiths of the Sierra Nevada and Peninsular Ranges, California, J. Geophys. Res., 87, 10,470-10,488.

Farmer, G. L., K. Licht, R. J. Swope, and J. Andrews (2006), Isotopic constraints on the provenance of fine grained sediment in LGM tills from the Ross Embayment, Antarctica, Earth Planet. Sci. Lett., 250, 72-88.

Francois, R., M. A. Altabet, E. F. Yu, D. M. Sigman, M. P. Bacon, M. Frank, G. Bohrmann, G. Bareille, and L. D. Labeyrie (1997), Contribution of Southern Ocean surface water stratification to low atmospheric $\mathrm{CO}_{2}$ concentrations during the last glacial period, Nature, 389, 929-935.

Frank, M., R. Gersonde, M. R. van der Loeff, G. Bohrmann, C. C. Nurnberg, P. W. Kubik, M. Suter, and A. Mangini (2000), Similar glacial and interglacial export bioproductivity in the Atlantic sector of the Southern Ocean: Multiproxy evidence and implications for glacial atmospheric $\mathrm{CO}_{2}$, Paleoceanography, 15, 642-658.

Franzese, A. M., S. R. Hemming, S. L. Goldstein, and R. F. Anderson (2006), Reduced Agulhas leakage at the LGM 
inferred from an integrated provenance and flux study, Earth Planet. Sci. Lett., 250, $72-88$.

Gersonde, R., X. Crosta, A. Abelmann, and L. Armand (2005), Sea-surface temperature and sea ice distribution of the Southern Ocean at the EPILOG Last Glacial MaximumA circum-Antarctic view based on siliceous microfossil records, Quat. Sci. Rev., 24, 869-896.

Goldstein, S. J., and S. B. Jacobsen (1988), Nd and Sr isotopic systematics of river water suspended material: Implications for crustal evolution, Earth Planet. Sci. Lett., 87, 249-265.

Goldstein, S. L., and S. R. Hemming (2003), Long-lived isotopic tracers in oceanography, paleoceanography and icesheet dynamics, in Treatise on Geochemistry, vol. 6, edited by H. D. Holland and K. K. Turekian, pp. 453-489, Elsevier, New York.

Goldstein, S. L., R. K. O’Nions, and P. J. Hamilton (1984), A $\mathrm{Sm}-\mathrm{Nd}$ isotopic study of atmospheric dusts and particulates from major river systems, Earth Planet. Sci. Lett., 70, $221-$ 236

Goldstein, S., N. T. Arndt, and R. F. Stallard (1997), The history of a continent from U-Pb ages of zircons from Orinoco River sand and $\mathrm{Sm}-\mathrm{Nd}$ isotopes in Orinoco basin river sediments, Chem. Geol., 139, 271-286.

Grousset, F. E., and P. E. Biscaye (2005), Tracing dust sources and transport patterns using $\mathrm{Sr}, \mathrm{Nd}$ and $\mathrm{Pb}$ isotopes, Chem. Geol., 222, 149-167.

Hays, J. D., J. Imbrie, and N. J. Shackleton (1976), Variations in the Earth's orbit: Pacemaker of the ice ages, Science, 194, $1121-1132$.

Heusser, C. J. (1989), Southern westerlies during the Last Glacial Maximum, Quat. Res., 31, 423-425.

Hodell, D. A., K. A. Venz, C. D. Charles, and U. S. Ninnemann (2003), Pleistocene vertical carbon isotope and carbonate gradients in the South Atlantic sector of the Southern Ocean, Geochem. Geophys. Geosyst., 4(1), 1004, doi:10.1029/ $2002 \mathrm{GC} 000367$.

Howard, W. R., and W. L. Prell (1992), Late Quaternary surface circulation of the southern Indian Ocean and its relationship to orbital variations, Paleoceanography, 7, 79-117.

Hurrell, J. W., and H. van Loon (1994), A modulation of the atmospheric annual cycle in the Southern Hemisphere, Tellus, Ser. A, 46, 325-338.

Intergovernmental Panel on Climate Change (2001), Climate Change 2001: The Scientific Basis: Contributions of Working Group 1 to the Third Assessment Report of the Intergovernmental Panel on Climate Change, edited by J. T. Houghton et al., 881 pp., Cambridge Univ. Press, New York.

Keeling, R. F. (2002), On the freshwater forcing of the thermohaline circulation in the limit of low diapycnal mixing, J. Geophys. Res., 107(C7), 3077, doi:10.1029/ 2000JC000685.

Keeling, R. F., and B. B. Stephens (2001), Antarctic sea ice and the control of Pleistocene climate stability, Paleoceanography, 16, 112-131.

Kirkham, R. V., and J. J. Chorlton (1995), Generalized geology of the world and linked databases, Geol. Surv. Can. Open File Rep., 2915d.

Klein, E. M., C. H. Langmuir, A. Zindler, H. Staudigel, and B. Hamelin (1988), Isotope evidence of a mantle convection boundary at the Australian-Antarctic discordance, Nature, $333,623-629$.

Kohfeld, K. E., and S. P. Harrison (2001), DIRTMAP: The geological record of dust, Earth Sci. Rev., 54, 81-114.

Kushner, P. J., I. M. Held, and T. L. Delworth (2001), Southern Hemisphere atmospheric circulation response to global warming, J. Climatol., 14, 2238-2249.
Lamy, F., D. Hebbeln, and G. Wefer (1999), High-resolution marine record of climatic change in mid-latitude Chile during the last 28,000 years based on terrigenous sediment parameters, Quat. Res., 51, 83-93.

Lamy, F., D. Hebbeln, U. Rohl, and G. Wefer (2001), Holocene rainfall variability in southern Chile: A marine record of latitudinal shifts of the southern westerlies, Earth Planet. Sci. Lett., 185, 369-382.

Lamy, F., C. Rühlemann, D. Hebbeln, and G. Wefer (2002), High- and low-latitude climate control on the position of the southern Peru-Chile Current during the Holocene, Paleoceanography, 17(2), 1028, doi:10.1029/2001PA000727.

Markgraf, V. (1989), Reply to Heuser's "Southern westerlies during the Last Glacial Maximum," Quat. Res., 31, 426432.

Matsumoto, K., J. Lynch-Stieglitz, and R. F. Anderson (2001), Similar glacial and Holocene Southern Ocean hydrography, Paleoceanography, 16, 445-454.

McCulloch, M. T., and G. J. Wasserburg (1978), Sm-Nd and $\mathrm{Rb}-\mathrm{Sr}$ chronology of continental crust formation, Science, 200, 1003-1011.

McLennan, S. M., and S. R. Hemming (1992), Samarium/ neodymium elemental and isotopic systematics in sedimentary rocks, Geochim. Cosmochim. Acta, 56, 887-898.

McLennan, S. M., S. R. Taylor, M. T. McCulloch, and J. B. Maynard (1990), Geochemical and Nd-Sr isotopic composition of deep-sea turbidites: Crustal evolution and plate tectonic associations, Geochim. Cosmochim. Acta, 54, $2015-$ 2050.

Moore, J. K., M. R. Abbott, and J. G. Richman (1999), Location and dynamics of the Antarctic Polar Front from satellite sea surface temperature data, J. Geophys. Res., 104, 30593073.

Moore, J. K., M. R. Abbott, J. G. Richman, and D. M. Nelson (2000), The Southern Ocean at the Last Glacial Maximum: A strong sink for atmospheric carbon dioxide, Global Biogeochem. Cycles, 14, 455-475.

Moreno, P. I., T. V. Lowell, G. L. Jacobson, Jr., and G. H. Denton (1999), Abrupt vegetation and climate changes during the Last Glacial Maximum and last termination in the Chilean Lake District: A case study from Canal de la Puntilla (41 ${ }^{\circ}$ S), Geogr. Ann., Ser. A., 81, 285-311.

Mortlock, R. A., and P. N. Froelich (1989), A simple method for the rapid determination of biogenic opal in pelagic marine sediments, Deep Sea Res., Part A, 36, 1415-1426.

Mortlock, R. A., C. D. Charles, P. N. Froelich, M. A. Zibello, J. Saltzman, J. D. Hays, and L. H. Burckle (1991), Evidence for lower productivity in the Antarctic Ocean during the last glaciation, Nature, 351, 220-223.

Ninnemann, U. S., and C. D. Charles (2002), Changes in the mode of Southern Ocean circulation over the last glacial cycle revealed by foraminiferal stable isotopic variability, Earth Planet. Sci. Lett., 201, 383-396.

Orsi, A. H., T. Whitworth III, and W. D. Nowlin, Jr. (1995), On the meridional extent and fronts of the Antarctic Circumpolar Current, Deep Sea Res., Part I, 42, 641-673.

Pollard, R. T., and J. F. Read (2001), Circulation pathways and transports of the Southern Ocean in the vicinity of the southwest Indian Ridge, J. Geophys. Res., 106, 2881-2898.

Prell, W. L., W. H. Hutson, D. F. Williams, A. W. H. Be, K. Geitzenauer, and B. Molfino (1980), Surface circulation of the Indian Ocean during the Last Glacial Maximum, approximately 18,000 yr BP, Quat. Res., 14, 309-336.

Pudsey, C. J., and J. A. Howe (1998), Quaternary history of the Antarctic Circumpolar Current: Evidence from the Scotia Sea, Mar. Geol., 148, 83-112. 
Pudsey, C. J., and J. A. Howe (2002), Mixed biosiliceous terrigenous sedimentation under the Antarctic Circumpolar Current, Geol. Soc. London, 22, 325-336.

Revel-Rolland, M., P. De Deckker, B. Delmonte, P. P. Hesse, J. W. Magee, I. Basile-Doelsch, F. Grousset, and D. Bosch (2006), Eastern Australia: A possible source of dust in East Antarctica interglacial ice, Earth Planet. Sci. Lett., 249, 1-13.

Rutberg, R. L., S. R. Hemming, and S. L. Goldstein (2000), Reduced North Atlantic Deep Water flux to the glacial Southern Ocean inferred from neodymium isotope ratios, Nature, 405, 935-938.

Sarmiento, J. L., and J. R. Toggweiler (1984), A new model for the role of the oceans in determining atmospheric $\mathrm{CO}_{2}$, Nature, 308, 621-624.

Sayles, F. L., W. R. Martin, Z. Chase, and R. F. Anderson (2001), Benthic remineralization and burial of biogenic $\mathrm{SiO}_{2}, \mathrm{CaCO}_{3}$, organic carbon, and detrital material in the Southern Ocean along a transect at $170^{\circ}$ west, Deep Sea Res., Part II, 48, 4323-4383.

Siegenthaler, U., and T. Wenk (1984), Rapid atmospheric $\mathrm{CO}_{2}$ variations and ocean circulation, Nature, 308, 624-626.

Sigman, D. M., and E. A. Boyle (2000), Glacial/interglacial variations in atmospheric carbon dioxide, Nature, 407, 859-869.

Sigman, D. M., S. L. Jaccard, and G. H. Haug (2004), Polar ocean stratification in a cold climate, Nature, 428, 59-63.

Sikes, E. L., C. R. Samson, T. P. Guilderson, and W. R. Howard (2000), Old radiocarbon ages in the southwest Pacific Ocean during the last glacial period and deglaciation, Nature, 405, $555-559$.

Stephens, B. B., and R. F. Keeling (2000), The influence of Antarctic sea ice on glacial-interglacial $\mathrm{CO}_{2}$ variations, Nature, 404, 171-174.
Stuut, J.-B. W., and F. Lamy (2004), Climate variability at the southern boundaries of the Namib (southwestern Africa) and Atacama (northern Chile) coastal desert during the last 120,000 years, Quat. Res., 62, 723-740.

Stuut, J.-B. W., M. A. Prins, R. R. Schneider, G. J. Weltje, J. H. F. Jansen, and G. Postma (2002), A 300-kyr record of aridity and wind strength in southwestern Africa: Inferences from grain-size distributions of sediments on Walvis Ridge, SE Atlantic, Mar. Geol., 180, 221-233.

Taylor, R. S., and S. M. McLennan (1985), The Continental Crust: Its Composition and Evolution, 312 pp., Blackwell, Malden, Mass.

Toggweiler, J. R. (1999), Variation of atmospheric $\mathrm{CO}_{2}$ by ventilation of the ocean's deepest water, Paleoceanography, 14, 571-588.

Toggweiler, J. R., J. L. Russell, and S. R. Carson (2006), Midlatitude westerlies, atmospheric $\mathrm{CO}_{2}$, and climate change during the ice ages, Paleoceanography, 21, PA2005, doi:10.1029/2005PA001154.

Trathan, P. N., M. A. Brandon, E. J. Murphy, and S. E. Thorpe (2000), Transport and structure within the Antarctic Circumpolar Current to the north of south Georgia, Geophys. Res. Lett., 27, 1727-1730.

van de Flierdt, T., S. L. Goldstein, S. R. Hemming, M. Roy, M. Frank, and A. N. Halliday (2007), Global neodymiumhafnium systematics-Revisited, Earth Planet. Sci. Lett., in press.

Walter, H. J., E. Hegner, B. Diekmann, G. Kuhn, and M. M. Rutgers Van Der Loeff (2000), Provenance and transport of terrigenous sediment in the South Atlantic Ocean and their relations to glacial and interglacial cycles: $\mathrm{Nd}$ and $\mathrm{Sr}$ isotopic evidence, Geochim. Cosmochim. Acta, 64, 3813-3827. 